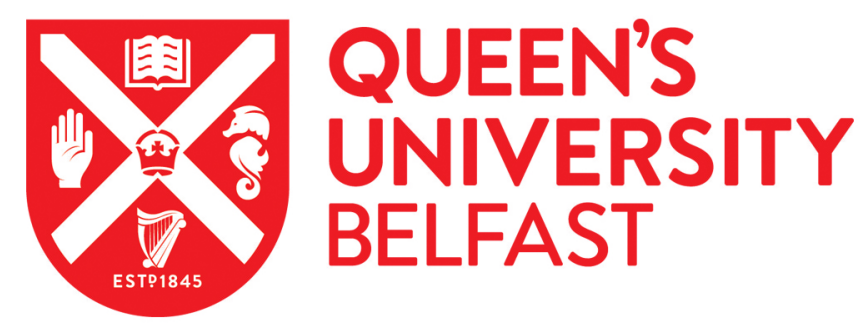

\title{
The Bestseller and the Blockbuster Mentality
}

McGowan, P. (2018). The Bestseller and the Blockbuster Mentality. In K. Curnutt (Ed.), American Literature in Transition, 1970-80 (pp. 210-225). (American Literature in Transition). Cambridge University Press.

Published in:

American Literature in Transition, 1970-80

Document Version:

Peer reviewed version

Queen's University Belfast - Research Portal:

Link to publication record in Queen's University Belfast Research Portal

Publisher rights

Copyright 2018 Cambridge University Press. This work is made available online in accordance with the publisher's policies. Please refer to any applicable terms of use of the publisher.

\section{General rights}

Copyright for the publications made accessible via the Queen's University Belfast Research Portal is retained by the author(s) and / or other copyright owners and it is a condition of accessing these publications that users recognise and abide by the legal requirements associated with these rights.

Take down policy

The Research Portal is Queen's institutional repository that provides access to Queen's research output. Every effort has been made to ensure that content in the Research Portal does not infringe any person's rights, or applicable UK laws. If you discover content in the Research Portal that you believe breaches copyright or violates any law, please contact openaccess@qub.ac.uk. 


\section{Chapter Twelve:}

\section{The Bestseller and the Blockbuster Mentality}

Philip McGowan

The 1970s was a decade of important cultural and literary interest in the history of the United States for manifold reasons: aside from the first attempted impeachment of a president in over a century, and the celebration of the nation's bicentennial marked by events that ran from April 1975 to July 4, 1976, the American literary world underwent a transition of irrevocable proportions. The restructuring of the publishing industry into a handful of large multi-national corporations, and the effects that this had on the literary marketplace, were seismic developments the consequences of which would be seen for the rest of the 20th century. In literary circles the decade brought the debuts of Toni Morrison, Jayne Anne Phillips, and Richard Ford, but also mourned the passing of John Dos Passos (1970), Ezra Pound and Marianne Moore (both 1972), and Vladimir Nabokov, Anaïs Nin, and Robert Lowell (all 1977). The turbulence that characterized the Nixon White House or the intrigues on Southfork ranch on CBS-TV's primetime soap opera Dallas also transferred to the world of publishing. A revolutionary transformation was underway that shifted the balance of sales power away from established authors connected to smaller publishers and toward a new breed of blockbuster writers who were contracted to, promoted by, and capitalized upon by the newly merged conglomerate publishing companies. The rise to global prominence of soon-to-be-established names such as Danielle Steel, Sidney Sheldon, and Stephen King as the most visible faces of the supremacy of mass-market paperback sales from the 1970 s forward was rooted in the decade's obsession with finding and selling the next big publishing phenomenon, be it a short-term bestseller or, better still, an unstoppable blockbuster. 
The hyper-commodification of cultural outputs, and of fiction writing in particular, in the 1970s was the necessary corollary of a structure designed to find, and then maintain, a bestseller culture. To this end, a self-perpetuating system based on the commercial potential of a bestselling work needed to be created and continually updated with new titles and their spin-off marketing potential. To produce such a self-sustaining organism and make it viable over time, the publishing industry must decide in advance what it believes the public "taste" or (next) current trend to be, then markets that "fact" to the public that in turn buys what is sold to it in large chain bookstores, supermarkets and retail outlet subdivisions of the main conglomerate corporation. Of all tools available to it, the bestseller list immaculately encapsulates this corporate taxonomy in operation. "The self-fulfilling nature of the list thus comes from the fact that the reading public is constantly bombarded with information about, and opportunities and incentives to buy books on the list—and buy they do," argues Laura J. Miller in relation to the pre-eminence of the New York Times bestseller list among other available records of reading trends. ${ }^{1}$ From the time The Bookman began producing monthly lists of fiction sales in 1895, an American interest in compiling, measuring and evaluating the success of a novel (and also non-fiction works such as cookery, etiquette, and crossword puzzle books) by the number of units sold was firmly established. The bestseller list is the most visible manifestation of an unfettered market in action and the ubiquitous nature of its role in late-19th- on through early-21st century culture is recognized in the proliferation of league tables and rankings for everything from local schools and hospitals to universities. Such lists matter because, basically, we are told that they do and, for the most part, we have accepted that premise without more rigorous scrutiny. Yet, bestseller lists — and particularly those of the 1970s - are intriguing documents of a culture in process. As Sarah Garland notes, "[w]hat we talk about when we talk about bestsellers is popular and commercial culture at its most noisy and dynamic." 2 The 1970s realigned the mainstream of U. S. publishing toward 
the commodification of the novel form and the potential to make vast sums of money through the tie-in opportunities presented by "event" publishing. As noisy and dynamic times go, it was a raucous decade.

Commodification, though, brings with it other pressures. The survival of the economically fittest may become the unspoken mantra of the system, yet knowing the sales figures of everything but not the distinction between the economic value of a text and its cultural significance creates an at best two-tier system rife with potential division. The aesthetic concerns of "serious" writing are pitted against purely financial payouts generated by typically derivative and formulaic novels that are everywhere for a moment and then, just as quickly, are gone to be replaced by the next mass-marketable title off the production line. As Fredric Jameson argues,

[w] ith the elimination of an institutionalized social status for the cultural producer and the opening of the work of art itself to commodification, the older generic specifications are transformed into a brand-name system against which any authentic artistic expression must necessarily struggle. The older generic categories do not, for all that, die out, but persist in the half-life of the subliterary genres of mass culture, transformed into drugstore and airport paperback lines of gothics, mysteries, romances, bestsellers, and popular biographies. $^{3}$

A bestseller, by definition, is a work that has sales potential over a specific, and usually limited, time period. As John Sutherland notes, not all paperbacks in the 1970s were destined for blockbuster status: “[u]p to 50 percent of all American paperbacks are reported to die on the shelf after an average of two weeks' display life."4 Not every paperback had the impact of 
Mario Puzo's The Godfather (1969), Peter Benchley's Jaws (1974) or Alex Haley’s Roots (1976); nor were they expected to, and neither did they have the marketing campaign, movie or television serialization deal in hand at the time of publication. The longevity of a title's popularity in the marketplace was not the primary focus of the publisher: cashing in on the cultural zeitgeist (itself the product of highly choreographed and intricate market forces) was the primary goal. For Jameson, and for Scott McCracken, previous understandings of the author-reader relationship are sacrificed in the culture of commodified production where "it is the image of the product, not the product itself that counts." 5 The novel as concept or as a vehicle for primarily commercial ends was replacing a more traditional understanding of the novel as a discrete, creative, and individual entity with a conservative print run in search of adulatory peer reviews.

Event publishing in the 1970 s capitalized both on the idea of a novel as sales weapon and its potential to participate in other markets beyond the purely book-based, whether in terms of merchandising, movie deals, or the production of sequels. As McCracken continues, "[t]he ability of the image of success to create more success suggests that in mass culture the popular text can cut loose from the conditions of its production and achieve a life of its own" (28). As an example of just such independence, the scale of the success of Peter Benchley's Jaws was unprecedented, both in terms of a publishing phenomenon and as a watershed cinematic event. The hardback was the third bestselling novel of 1974 with 202,270 copies sold, while the paperback edition, timed to coincide with the release of the Steven Spielberg movie across theaters in the summer of 1975, brought in a further eight million sales. ${ }^{6}$ Moreover, the film adaptation topped the domestic grossing list with takings of $\$ 129,500,000$, more than double the next highest grossing film of 1975, One Flew Over the Cuckoo's Nest, with $\$ 60,000,000$. Jaws is credited with "initiat[ing] the era of the Hollywood blockbuster," earning $\$ 100,000,000$ of its gross earnings within six months of its release proving, according 
to Douglas Gomery, that "one film under careful guidance from its distributor, in this case Universal, could precipitate a national pop cultural 'event,' and make millions upon millions of dollars for a single studio with but a single film." ${ }^{, 7}$ Blockbuster had become the hot and fashionable term in the studios of Hollywood as well as in the offices of mainstream American publishing, the two arenas in effect the paired and increasingly interdependent armatures of enormous conglomerate organizations.

Cover design is one obvious area that illustrates this interdependence. The famous graphic that helped propel the Jaws craze - an oversized, menacingly toothed Great White shark speeding upwards from the depths toward a naked swimming woman-was born in the offices of the novel's paperback publisher, Bantam, which hired illustrator Roger Kastel to improve upon the more impressionistic hardback cover by Paul Bacon. (Such were the similarities between the covers' basic design elements that Doubleday successfully sued Bantam for a cut of the paperback profits). When Universal executives saw Kastel's work they instantly licensed it for use as the movie poster, albeit with different color tinting. The combination of the image and the typeface spelling out the ominous, four-letter title - not to mention the title's blood-red lettering - was so arresting that the cover art/poster became a de facto logo, reprinted on toys, towels, and T-shirts, and parodied ad infinitum by the likes of Mad Magazine and political cartoonists. Hollywood was so smitten with Kastel that he went on from a career as a freelance book-cover illustrator (among thousands of other paperbacks, he did the cover for Richard Price's The Wanderers [1974]) to one of the movie business's premier poster designers, his art for the second Star Wars installment, The Empire Strikes Back (1980), considered one of the most influential movie posters ever. ${ }^{8}$ Yet the omnipresence of the Jaws graphic effectively undermined the status of Benchley's novel as an autonomous piece of popular art, rendering it a mere adjunct of a franchise, an 
entertainment to be experienced alongside the pleasures of playing Jaws games, lounging in the pool on inflatable Jaws flotation devices, and slugging back from Jaws shot glasses.

It probably did not help Benchley's literary reputation that most commentators considered the movie far superior in plot construction and the likability of the characters to his Jaws. Even Spielberg went on record about the book's defects, telling the press, "If we don't make this movie better than the book, we're in real trouble," sparking a long and tangled spat between the director and the writer. ${ }^{9}$ Benchley found his standing as a blockbuster writer swallowed whole not just in the broader entertainment industry but within publishing itself. As Jaws-mania swept the U. S. in 1975, one of the movie's screenwriters, Carl Gottlieb, published The Jaws Log with Dell, telling the story of the making of the novel, the negotiations that went into hiring Spielberg and stars Roy Scheider, Robert Shaw, and Richard Dreyfuss, the infamous on-set technical problems with the mechanical shark nicknamed "Bruce," and quibbles over the shooting script. Gottlieb even wrote about Benchley's cameo as a TV reporter in the film, depicting him rather unflatteringly as a nuisance whining about the creative liberties taken with his text. The Jaws Log was far from the only publishing cash-in during the killer shark merchandising frenzy. Ballantine published Edith Blake's The Making of the Movie Jaws, which described the on-set tensions from the perspective of Martha's Vineyard locals who observed the protracted shooting schedule in 1974 as the novel rose on the bestseller lists. Such "tie-in" paperbacks were produced to promote film adaptations of literary classics as well as bestsellers headed to the silver screen: as Jack Clayton's tepid version of The Great Gatsby starring Richard Redford and Mia Farrow racked up \$26 million in box office in spring 1974, sparking a 1920s’ fashion renaissance, Berkley Medallion cranked out Bruce Bahrenburg's The True, BehindThe-Scenes Account of Filming The Great Gatsby, its back cover copy promising to reveal how, rather optimistically, "the great novel of the twenties was turned into the great movie of 
the seventies." While this quickie book harmed neither the reputation of F. Scott Fitzgerald nor his 1925 novel, tie-ins did diminish Benchley’s standing. By the time he tried to follow up his gargantuan Jaws success with a second novel, The Deep (1976)—whose inevitable movie version, released the following year, based its own relentless promotional blitz on the Jaws precedent - he was largely disregarded as a novelist and considered more of a cog in a corporate enterprise, a writer willing to create fiction from a blueprint for manufacturing blockbusters.

Other writers found themselves on the sidelines of the franchises they helped create. After the massive success of both Hotel (1965) and Airport (1968), Arthur Hailey spent the 1970s laying claim to the peculiar niche these bestsellers established, in which Hailey combined meticulous research into a specific industry—often focusing on their business or operational protocols, safety, and office politics — with interpersonal plots straight out of soap operas (lots of adultery and alcoholism). 1971's Wheels explored the Detroit automotive industry, while 1975's The Moneychangers examined the American banking system and 1979's Overload took on California's electricity-production industry. All of these novels sold handsomely, but the popularity of the movie version of Airport (1970), which ignited the decade's kitschy trend for disaster films such as 1974's The Towering Inferno and 1975's Earthquake, overshadowed these subsequent efforts. This was in large part because the disaster-movie fad included three Airport sequels, each named after a year: Airport '75, Airport '77, and The Concorde ... Airport '79. As Hailey's wife recounted in a 1978 memoir entitled - appropriately enough - I Married a Bestseller, the writer was shocked to learn of the release of Airport '75 through a newspaper report instead of the studio that originally adapted his novel informing him of their franchise plans. Hailey was only mollified at not being consulted by receiving a substantial payment and credit for "inspiring" the sequels. Hailey also received a cut of the "novelizations" of the three subsequent movies, another 
1970s' tie-in trend that eroded the aesthetic standing of the novel genre. If a hit movie was not based on a novel, publishers produced cheap paperbacks that translated the scripts into novel format. Hailey was rather miffed when readers mistook him as the author of these disposable efforts: "There is also a novel now," Mrs. Hailey writes with exasperation, "based on the movie Airport '77. Arthur did not write this either, though we do have a financial interest in it, due to Arthur's authorship of the original Airport novel ... but, oh my goodness, let's not get into that!"10

The French writer Pierre Boulle enjoyed an even more pronounced literary as opposed to popular status like Hailey's that found his standing subsumed within the success of a franchise based on his work. The author of Bridge over the River Kwai (1952) was more than happy that 1963's La planète des singes (originally translated as Monkey Planet) inspired the 1968 science-fiction classic Planet of the Apes and its four sequels, two TV shows, and innumerable novelizations alone in the 1970s. He even drafted a screenplay for the first sequel, 1970's Beneath the Planet of the Apes, and consulted on various spin-offs. Yet the prominence of the Apes franchise overwhelmed his estimable 1970s' novels, including 1972's Ears of the Jungle, a sterling Vietnam tale. The degeneration of his original satire on human chauvinism into a literal cartoon by the mid-1970s, with toys, masks, and games marketed to children, increasingly caused him to consider La planète des singes one of his lesser works. While he enjoyed the revenue stream, he also resented the impact of the franchise on popular culture, and thought of himself as a novelist of ideas rather than as the science-fiction writer he was often erroneously identified as. ${ }^{11}$

Some of the major-selling successes of the decade were not so much engineered and sustained through franchising but were either surprise hits or examples of fortunate, indeed serendipitous, events. Richard Bach's Jonathan Livingston Seagull topped the bestseller lists in both 1972 and 1973 though had initially failed to find publishing success when it was first 
released in 1970 (then titled Jonathan Livingston Seagull—A Story). Bach's short work, a photo-illustrated 10,000-word tale of a seagull's search for independent achievement and happiness, was taken up by Macmillan and consequently "broke all hardcover sales records since Gone With the Wind." 12 Although its 1973 movie version was neither critically nor commercially successful, the "event" portion of the book's multi-media adaptation was admirably fulfilled by the film's soundtrack, which was written and performed by singer Neil Diamond. The LP reached No. 2 on the Billboard charts and won both a Grammy and Golden Globe for Best Original Score, maintaining interest in the book until the mid-1970s. Jonathan Livingston Seagull was one of three animal-centered fictional works to achieve bestseller status in this decade, the other two coming in 1974: Benchley's Jaws and Richard Adams's Watership Down, though it must be noted that Charles Schulz had continued success throughout the 1970s with further installments of his Peanuts and Charlie Brown cartoon books. Elsewhere, the sensation that was William Peter Blatty's The Exorcist (1971) had more to do with an extended and unexpected slot on The Dick Cavett Show than the credibility of the plot or Blatty's own writing abilities. Filling in for a missing guest, Blatty pitched his tale of demonic possession, which Cavett had not yet read, for forty-five minutes, his enthusiasm for his own work singlehandedly resurrecting the fortunes of a book that "had actually been dead on arrival at bookstores," with copies being returned to him by his publisher Harper \& Row for "fifty cents each"13 — and this after Blatty had conducted "a 26city tour with 12 to 13 interviews a day" (King). The Exorcist would top the bestseller lists of 1971 for seventeen weeks, selling almost half a million hardcover copies, four million in paperback, and another four million after the release of William Friedkin's film adaptation in 1973 (Konow 139). 
Analyzing a decade's or even just a single year's literary output primarily in terms of its bestseller lists is both an intriguing but potentially self-defeating task. Data and statistics jostle for primacy in the count of what counts ahead of questions of aesthetics, achievement, "seriousness," or value. How a bestseller list is compiled, what it includes within its statistical argument and what it does not, opens up the possibility that none of the excess of information is ultimately reliable and, thus, cannot give a true version of reading tastes at any given time. Is one bestseller list, for instance the New York Times list, better than a list from another region in the United States, or do national lists provide a more accurate reflection of the reading state of the nation? On what grounds can such a question be determined or a position either way supported? The issue of how bestseller lists are created is as fraught as the ends to which they are put: rather than offering an objective overview of a point in time, bestseller lists are the most publicly visible commercial aspect of a hugely commercialized business and are deployed by publishing companies precisely to generate more revenue for any given title. As a term, as Sarah Garland notes, bestseller is "always hyperbole" (39) and the lists that are produced "represent the already read in both senses of the phrase; they represent books that have been consumed and statistics that come to us interpreted" (41). As readers of these lists after the event, we should approach them aware that the histories that they tell are not objective testaments to what was selling well or not so well, but as manipulated registers of commercial importance providing us with insights into the competitive worlds of conglomerate publishing: "[t]he history of American 'bestsellers' as told by the bestsellers' lists is not so much a history of stock-taking and accounting as a history of discourse — of comment, interpretation, and opinion" (40). As prime examples of the uses and misuses of statistical data, the bestseller lists reveal as much information as they conceal, their face value a double front of an excess of seemingly transparent information contained within a preordained set of categorizations. 
Caveats aside, the endeavour of attempting to construct a critical picture of the 1970s in U. S. writing via bestseller lists is one that raises a series of connected and compelling, if wholly casual, relations. Side-by-side with the familiar and household names stand the soonforgotten authors; popular high-selling titles rub shoulders with the works of authors deemed to be of more literary, and lasting, merit. Writing in 1971, Anthony Burgess acknowledged a recurring flaw at the heart of using bestsellers as an indication of anything other than lowest common denominator populism: "[v]ery occasionally the best book and the bestseller coincide, but generally the books that make the most money are those which lack both style and subtlety and present a grossly oversimplified picture of life. Such books are poor art, and life is too short to bother with any art that is not the best of its kind." Burgess has a point, and he proceeds to examine the "quietly meritorious" and "moderate sellers with something permanent to give" who "go steadily but unspectacularly on, finding a lasting place in the history of the novel." ${ }^{14}$ Yet, in so doing, he pushes an agenda that seeks to dismiss what value exists in many of these popular works as bestsellers, as examples of where a country and its book-buying public's interests lie at any given point in time.

The shifting landscape of reading habits in the United States as the 1970s unfolded reflected the fact that more room was being made available in the marketplace for middlebrow tastes to dominate the bestseller lists and the future publication agendas of the major publishing houses. While established writers as well as critics of highbrow literature may have wished to hold the line against this invasion from what is best described as the mainstream, they were simultaneously guilty of resisting a vital, if challenging, dimension of their market which they needed to maintain their own livelihoods. As Paul J. DiMaggio persuasively argues via Pierre Bourdieu's articulation of cultural as opposed to financial value, "[a]lthough 'middlebrow' products were not to the liking of critics with the greatest stake in maintaining an unwatered cultural currency, they were essential in constituting as 
cultural capital a public version of the culture that the critics valued." ${ }^{15}$ Burgess, for one, can find "no space to consider" such popular authors for whom "the general public has such a high regard"; his delineation of "the novel now" is for "the informed part" of a 1971 audience that knows authentic literary value and "real best-selling" from " $[\mathrm{t}]$ he other kind [which] is too tempestuous to last for more than a season" (20-21). Ultimately, however, this is why the 1970s was an intriguing period within U. S. publishing history: the ability of a text to be all the rage, and then suddenly not, or to spawn a gross-selling movie adaptation and its own range of plastic accessories and figurines makes this tempestuous moment all the more fascinating to cultural critics today.

It is clear that the 1970s and its generation of mass-market blockbuster publishing opportunities occupies a significant place within the long history of American publishing. Indeed, as Sutherland argues specifically in relation to bestselling books, "what is useful about such culturally embedded works is what they tell us about the book trade, the market place, the reading public and society generally at the time they have done well" (3). As Garland evidences, the difficulties inherent within defining what a bestseller is (what counts, who is doing the counting and for whom, and over what period of time?) produce debates about the merits of having bestseller lists and to what ends they are put by publishers. What is clear when looking at the publishing industry in the United States in the 1970s is that the concept of the high-selling book and the pursuit of the next blockbuster title drove the market forward on almost purely economic and financial determinants. Sales trumped literary merit as the largest conglomerate companies outbid each other in securing rights, shelf space and movie tie-in deals. Moreover, and this is where traditional concepts of the author and literary creation become somewhat confused in the spree of 1970s' blockbuster culture, the book as an entity produced by a single intelligence was superseded in this hothouse environment by teams of "agents, editors and salesmen" capable of claiming "“credits' in an essentially 
corporate venture" (Sutherland viii). The new producers in this brand of cultural economy epitomize Bourdieu's "masters of thoughtless thought" intent on "monpoliz[ing] public debate" through a range of tactics and

specific powerplays such as surveys aiming to produce manipulated classifications, or the 'top ten' lists which newspapers publish on anniversary occasions, and so forth, or even publicity campaigns aiming to discredit productions destined for the narrow (and long-term) market at the expense of the products of wide circulation and short cycle which new producers launch onto the market. ${ }^{16}$

Major changes in the post-World War II publishing landscape were initially evident in the 1960 s when a series of smaller or independent publishing firms merged with—or disappeared into — the larger firms such as Random House: for example, Random bought over Alfred A. Knopf in 1960 from monies accrued from Random's thirty percent flotation on Wall Street the previous year. In the 1970s, this trend continued: "Random House bought Ballantine; Holt, Rinehart and Winston bought Bantam and Popular Library; Harcourt Brace Jovanovich bought Jove; Simon \& Schuster bought Pocket; and Doubleday bought Dell." ${ }^{\text {17 }}$ Add to this Sutherland's argument that "the 1970s would seem to have witnessed a genuine paperback revolution" (21) and it becomes easier to comprehend how, as Thomas Whiteside outlines it, "the entire economy of trade-book publishing [in the 1970s] has become focused on the pursuit of 'the big book' — the so-called blockbuster." With publishers outdoing each other in bidding for the rights to publish "the next big thing," "the actual sums offered for mass-market-paperback reprint rights to actual or potential best-sellers have mounted rapidly on their own momentum" (Whiteside 19). In The Rules of Art Bourdieu acknowledges the 
existence of commercial literature as a not-recent development: "nor is it new that the necessities of commerce make themselves felt at the heart of the cultural field. But the grip of the holders of power over the instruments of circulation — and of consecration - has undoubtedly never been as wide and as deep as it is today — and the boundary has never been as blurred between the experimental work and the bestseller" (347; emphasis in original). What Bourdieu atomizes here correlates perfectly with the maneuvers of publishers in the U. S. in the 1970s (and after) during which time "an even larger part of cultural productionwhen it is not coming from people who, since they work in the media, are guaranteed the support of the media - is predefined, down to date of appearance, title, format and size, content and style — to catch the attention of journalists who will make it exist by speaking about it" (346-47). Novels did not necessarily have to be completed before the marketing team got to work or the rights to the paperback edition or the movie adaptation were up for auction. For example, William Targ of Putnam's bought Mario Puzo's The Godfather for an advance of $\$ 5,000$ in 1967 , and then "sold the paperback rights to Fawcett for four hundred and ten thousand dollars" (Whiteside 152); in terms of the film, Francis Ford Coppola worked with galley proofs of the novel, which itself was "published while the film was in production" (Stringer 2003: 23), the two texts, aided by accompanying media attention, simultaneously generating mutual interest in the other. Producers Darryl Zanuck and David Brown, meanwhile, developed Jaws while Benchley's novel was in draft form. Later, news reports of the movie's filming helping maintain the hardback's ascendancy on the bestseller charts throughout 1974.

For established authors more associated with the writing of "serious literature" read by the self-selecting minority, these new and pervasive publishing practices brought a whole new meaning to the term competition. Yet, as James L. W. West III highlights, and agreeing with Bourdieu, a commercialized environment of attempting to unearth a bestseller was not 
an altogether new phenomenon within American publishing. Indeed, the opposite, more than anything, is the case. Quoting Henry Holt's "The Commercialization of Literature" in Atlantic Monthly from November 1905, West reveals the similarities that define the profitmaking interests of the publishing industry. For Holt,

[n]ot as many books pay for themselves as they did before; but the few that do sell, sell more widely, and thus may still do their share to pay the losses and expenses on the rest. Hence the mad quest of the golden seller, the mad payment to the man who has once produced it, and the mad advertising of doubtful books in the hope of creating the seller,- - by pictures, dummies, big letters and other methods fit only for candy, whiskey, tobacco, and other articles of unlimited sale. All this reacts, as has been explained, to crush out all books but the seller. ${ }^{18}$

While competition within the field of publishing at the start of the 20th century was similarly marked by the pursuit of the next successful book that would outsell its rivals, by the 1970s it could be argued that the situation suddenly switched to overdrive. In the wake of company mergers and the evolution of the conglomerate business model, West usefully, and pointedly, deploys the analogy of the National Basketball Association (NBA) to discuss the fallout within U. S. publishing after the 1960s:

The factors that have damaged professional basketball are similar to those that have altered the publishing industry: ownership by people who do not understand the business fully, overproduction and consequent dilution of talent, the influx of big money from subsidiary rights, agents as a negotiating 
force, the absence of loyalty in employer-employee relationships, the influence of media fame, the tendency to buy already developed talent rather than to bring up young talent through an apprenticeship system, the tendency of sports writers (like book critics) to concentrate on imagery and personality rather than on acquired skill. (149)

Unlike other commentators on the changing face of U. S. publishing in the last decades of the 20th century, West does not see all of this as necessarily bad news. With potentially much wider reading audiences to be accessed through improved communications systems and technologies, the positive side of the publishing revolution needs to be recorded as much as any negative aspects. Moreover, with authors now earning more money for their work, the situation represents a profitable turn in many respects, at least for the big name writers who recurringly appear on the bestseller lists. An unexpected upshot of the conglomeration of the publishing industry, for West, would be increased engagement with a broader cross-section of American society: "[t]he conglomerate executives may not know it, but in the end they may be a force that helps give modern American literature the broad audience it has always needed but until now has had little chance of reaching" (154). With more people choosing to read contemporary fiction, so the argument goes, the higher the chance that highbrow novels would also be swept along in the fervor. All boats rise on a rising tide, after all.

Indeed, it would be erroneous to claim that all of the 1970s bestsellers were populist, low- or middlebrow books. Kurt Vonnegut's Breakfast of Champions was the third bestselling book of 1973, Something Happened by Joseph Heller the fifth best of the following year, and E. L. Doctorow's kaleidoscopic reimagining of the first decades of the 20th century, Ragtime, topped the bestselling lists of 1975. That achievement, though, should 
be set against a broader trend across the publishing industry: sales of hardcover novels were in decline, in part due to the explosion of mass-market softcover sales. As Hackett notes, only Ragtime and Arthur Hailey's The Moneychangers sold over 200,000 copies that year (218); in comparison the "cynically conceived schlock" that was Erich Segal's Love Story topped the 1970 bestselling lists with over 400,000 sales (Hackett 208). ${ }^{19}$ Undoubtedly, an old regime characterized by serious writing by serious authors for a serious audience was being replaced by a rolling diet of faddish fictions that in essence were instantaneously disposable. That said, the revolution was not all-encompassing, and the proportion of literary authors to their short-term bestselling counterparts in the 1970s bestseller lists is roughly parallel to the situation in, for example, the 1920s when authors like Edith Wharton and Sinclair Lewis, for instance, vied for sales with arguably more populist authors Zane Grey, John Galsworthy and Arthur Hutchinson.

Taken as a decade in its own right there is another possibly significant trend that identifies the 1970 s as a decade of renewed interest to literary historians. Hackett notes that five of the top ten bestselling novels of 1969 were "not notable for literary quality, but rather for eroticism" and, indeed, were "deplored by the critics" (206): Jacqueline Susann's The Love Machine (third bestselling novel of the year); followed by Harold Robbins' The Inheritors in fourth place; in sixth, The Seven Minutes by Irving Wallace; in seventh, Naked Came the Stranger written by a number of journalists under the pseudonym Penelope Ashe; and Gwen Davis' The Pretenders, the year's ninth bestselling fictional work. In addition, the year's two top sellers, Philip Roth's Portnoy’s Complaint, and Mario Puzo's The Godfather, were not devoid of sexual content either as the 1960s came to a close with both bangs and whimpers. Hackett suggests that the success the following year of Love Story and John Fowles' The French Lieutenant's Woman (second on that year's bestselling list) may have served as a moral corrective to the previous year's sexual excesses: "traditional" romance 
was back in the nation's hearts, for one year at least. Fast forward to the 1980 s - and then broadly representative of the rest of the century - the romance genre and "sex and shopping" novels would dominate. As Sarah Churchwell highlights, “[f]or exactly two decades between 1980 and 2000, blockbuster epic romances written by Danielle Steel, Judith Krantz, Sidney Sheldon, Jackie Collins, Jean M. Auel dominated the US bestseller lists, accounting for between four and six of the top ten bestselling novels in each of those 20 years without exception, according to Publishers' Weekly's annual lists."20 The 1970s was the decade that witnessed the transition from "serious" writing to mass-market successes as paperbacks outsold hardcover novels in the push for new audiences. James English corroborates this popcultural turn in the 1970s marking a sea change in the relation between award-winning fictions, or culturally "consecrated" texts, to borrow Bourdieu's phrase, and the lists of bestsellers and blockbuster fictions: "[f]rom the 1920s through the 1960s, roughly half of all Pulitzer winners were drawn from the top-ten bestsellers of the previous and/or current year. Since then, only one of more than thirty winners has come from this most commercially successful sector of published fiction." ${ }^{21}$ This in itself is a remarkable statistic and it signposts a changing of the guard, in literary terms, across the U. S. since the 1970s. It constitutes a polarizing swing in the public's attitude to literary fiction, underpinned by a publishing industry keen to maximize its profit margins wherever possible. The two trends coalesce to produce a new landscape for American writing in the period: in terms of what is being published, whether mass-market or highbrow literary texts; what is cornering the market in terms of bestsellers; and what is achieving recognition or esteem within critical circles.

If new variations on the theme of romance were proving their popularity so, too, were books (and later films) centered upon a disaster storyline. Benchley's Jaws arguably initiated a series of other tales of down-home communities under siege from plagues of malignant 
animals, insects or rodents: Sutherland lists "dogs, rats, bats, crocs, worms, alligators, spiders, piranha, crabs, rattlers, frogs" among the invading forces in narratives that, like Jaws, proffer an essentially conservative agenda requiring "constant vigilance in a society forever on guard against mysterious, unpredictable visitations" (77). Most notable among these were The Swarm (1974) by Arthur Herzog, later a 1978 movie starring Michael Caine, in which killer African bees descend upon Manhattan (relocated to Texas in Irwin Allen's film adaptation); and Kingdom of the Spiders, a 1977 novel by Bernhardt J. Hurwood about an Arizona town overrun by arachnids which was released as a film, also in 1977, starring William Shatner of Star Trek fame. Terror of a different source inspired the success of David Seltzer's The Omen (1976). Seltzer had initially failed to see his screenplay develop after he had sold it to Warner, but when Twentieth-Century Fox optioned it for production, Seltzer completed the novel, though played no part in the sequels Damien: Omen II (1978), written by Joseph Howard, or the three later installments released in 1980, 1983 and 1985 and all penned by Gordon McGill.

The nonfiction bestseller of 1977, Alex Haley's Roots, became a blockbuster success on the back of its television serialization by ABC-TV. Initial hardcover sales of 600,000 almost doubled, to 1,100,000, in the first two years alone; by 1979, "combined hardcover and paperback sales ... had reached nearly six million.” Indeed, the mini-series was so successful it attracted "an audience of well over a hundred million people, and attendance at movie theatres in the country is said to have dropped between forty and fifty percent" (Whiteside 71). Popularity was big business and vice versa, both undoubtedly playing a part in the July 1979 Association of American Publishers' decision to replace the National Book Awards with the American Book Awards. Simultaneously the awards were expanded to include "current interest" titles, a move that was interpreted by highbrow publishers as a downscaling of the national awards due to pressure from the multinational conglomerates. Farrar, Straus \& 
Giroux, for one, withdrew all of its titles from the newly inaugurated award system citing their "emphasis on marketing and industry public relations offensive to anyone concerned with the disinterested recognition of literary merit" (Whiteside 94). This stance was followed later that year by a letter of protest, drawn up by Alison Lurie and co-signed by forty-four other authors, among them Saul Bellow, Philip Roth, Susan Sontag, Nelson Algren, Bernard Malamud, Alfred Kazin, Wallace Stegner, and Richard Wilbur, that denounced the new awards as "a rubber stamp prize for best-sellers" and called on other writers as well as critics to boycott them. Despite this, the 1980 awards proceeded, though Roth, Norman Mailer and William Styron withdrew their nominated books because the awards, in their view, were the product of "commercial and public-relations concerns that should have little to do with the recognition of literary merit" (Whiteside 94). As noted earlier, the tide toward bestseller domination of the American publishing industry had thoroughly been turned.

\section{Notes}

${ }^{1}$ L. J. Miller, “The Best-Seller List as Marketing Tool and Historical Fiction.” Book History 3 (2000), 295.

${ }^{2}$ S. Garland, "Missing Numbers: The Partial History of the Bestseller," in S. Churchwell and T. Ruys Smith (eds.), Must Read: Rediscovering American Bestsellers from Charlotte Temple to The Da Vinci Code (London: Continuum, 2012), 38. Subsequent references will be cited parenthetically in the text.

${ }^{3}$ F. Jameson, The Political Unconscious: Narrative as a Socially Symbolic Act (Ithaca: Cornell University Press, 1981), 107.

${ }^{4}$ J. Sutherland, Bestsellers: Popular Fiction of the 1970s (London: Routledge and Kegan Paul, 1981), 23. Subsequent references will be cited in the text. 
${ }^{5}$ S. McCracken, Pulp: Reading Popular Fiction (Manchester: Manchester University Press, 1995), 28. Subsequent references will be cited in the text.

${ }^{6}$ A. P. Hackett and J. H. Burke, 80 Years of Best Sellers 1895-1975 (New York and London: R.R. Bowker Company, 1977), 216; T. Whiteside, The Blockbuster Complex: Conglomerates, Show Business, and Book Publishing (Middletown, CT: Wesleyan University Press, 1981), 29.

${ }^{7}$ D. Gomery, “The Hollywood Blockbuster: Industrial Analysis and Practice," in J. Stringer (ed.), Movie Blockbusters (New York: Routledge, 2003), 72-73.

${ }^{8}$ B. Marks, "The Bizarre Story of How the Original Poster for Jaws Went Missing."

Gizmodo August 14 2014. http://gizmodo.com/the-bizarre-story-of-how-the-original-posterfor-jaws-w-1621658366

${ }^{9}$ Qtd. in N. Andrews, Jaws: A Bloomsbury Movie Guide (London: Bloomsbury, 1999), 22.

${ }^{10}$ S. Hailey, I Married a Bestseller: My Life with Arthur Hailey (New York: Doubleday, 1978), 160.

${ }^{11}$ L. F. Becker, Pierre Boulle (New York: Twayne, 1996), 77.

${ }^{12}$ C. Bloom, Bestsellers: Popular Fiction Since 1900. 2nd Ed. (Basingstoke: Palgrave Macmillan, 2008), 229.

${ }^{13}$ Quoted in S. King, "William Peter Blatty reflects on $40^{\text {th }}$ Anniversary of The Exorcist" in Los Angeles Times 8 October 2013 (latimes.com/entertainment/movies/moviesnow/la-et-mnwilliam-peter-blatty-exorcist-20131008-story.html); D. Konow, Reel Terror: The Scary, Bloody, Gory Hundred-Year History of Classic Horror Films (New York: St Martin's Griffin, 2012), 138. Subsequent references to both works are cited in the text.

${ }^{14}$ A. Burgess, The Novel Now: A Student's Guide to Contemporary Fiction (London: Faber and Faber, 1971), 20-21. Subsequent references are cited in the text. 
${ }^{15}$ P. DiMaggio, "Social Structure, Institutions, and Cultural Goods: The Case of the United States" in P. Bourdieu and S. J. Coleman (eds.), Social Theory for a Changing Society. Boulder: Westview Press, 1991, 141.

${ }^{16}$ P. Bourdieu, The Rules of Art: Genesis and Structure of the Literary Field. Trans. S. Emanuel (Cambridge: Polity Press, 1996), 346 (emphasis in original). Subsequent references are cited in the text.

${ }^{17}$ B. Luey, "The Organization of the Book Publishing Industry,” in D.P. Nord, J. Shelley Rubin, and M. Schudson (eds.), A History of the Book in America: Volume 5 The Enduring Book: Print Culture in Postwar America (Chapel Hill: University of North Carolina Press, 2014), 48 .

18 J. L. W. West III, American Authors and the Literary Marketplace Since 1900 (Philadelphia: University of Pennsylvania Press, 2011), 152. Subsequent references are cited in the text. See also H. Holt, "The Commercialization of Literature." Atlantic Monthly 96 (November 1905): 577-600.

19 The phrase "cynically conceived schlock" comes from Sutherland's 2007 distillation of the 1981 study quoted throughout this essay. See Bestsellers: A Very Short Introduction (New York: Oxford University Press, 2007), 22.

${ }^{20}$ S. Churchwell, "Master of Sentiment: The Romances of Nicholas Sparks," in Churchwell and Ruys Smith (eds.), Must Read: Rediscovering American Bestsellers From Charlotte Temple to The Da Vinci Code. London: Continuum, 2012, 298.

${ }^{21}$ J. F. English, The Economy of Prestige: Prizes, Awards, and the Circulation of Cultural Value (Cambridge, Mass. and London: Harvard University Press, 2005), 330-31. For Bourdieu on "consecrated" texts, see The Field of Cultural Production: Essays on Art and Literature, (ed). Randal Johnson (Cambridge: Polity Press, 1993), 120-21. 